Fedorova Lyudmyla, Senior lecturer

ORCID: 0000-0002-6620-3041

Researcher ID: N-3556-2016

Zaitseva Iryna,

$\mathrm{PhD}$ (Pedagogical Sciences),

Associate Professor

ORCID: 0000-0002-9958-5226

Researcher ID: B-8714-2019

Gopanchuk Iryna,

$\mathrm{PhD}$ (philological sciences),

Kyiv National University of Trade and Economics, 19, Kyoto str., Kyiv, 02156, Ukraine

ORCID: 0000-0003-1399-6364

Researcher ID: N-6278-2016

\title{
LANGUAGE TRAINING IMPROVEMENT OF LAW STUDENTS AT UKRAINIAN HIGHER EDUCATIONAL INSTITUTIONS
}

In the article language, speech and communicative competences of the most common legal professions, such as judges, prosecutors, lawyers, notaries have been described. The authors have proved the importance and necessity of language training improvement of law students. The proposal to specify the requirements for speech activity in the professiograms of legal professionals has been made, because their formation level of language, speech and communicative competences is an indicator of their readiness for future professional activity.

Keywords: language competence, speech competence, communicative competence, professional competence, the professiogram of a lawyer.

Федорова Людмила, Зайцева Ірина, Гопанчук Ірина. Удосконалення мовної підготовки юристів у вищих навчальних закладах Украӥни.

У статті здійснено опис мовних, мовленнєвих $і$ комунікативних компетентностей найбільш поширених юридичних професій, зокрема судді, прокурора, адвоката, нотаріуса. Доведено важливість і необхідність удосконалення мовної підготовки студентів, які навчаються за спеціальністю «Право». Зроблено пропозицію конкретизувати вимоги до мовленнєвої діяльності у професіограмах спеціалістів юридичного профілю, адже рівень сформованості в них мовних, мовленнєвих $і$ комунікативних компетентностей є показником їх готовності до майбутньої професійної діяльності.

Ключові слова: мовна компетентність, мовленнєва компетентність, комунікативна компетентність, професійна компетентність, професіограма юриста. 
Relevance of the research topic. Due to the updating of content and forms of higher legal science and education in Ukraine, the approval of the state status of the Ukrainian language, especially after the Law of Ukraine «On ensuring the functioning of the Ukrainian language as a state language» was adopted by the Verkhovna Rada on 25.04.2019, the research topic is of high relevance. Taking into account the increasing role of the Ukrainian language in comprehension of nation-building and nation-wide processes, there is an urgent need to improve the linguistic training of law students in higher education.

Modern professional training of law students in higher educational institutions should be aimed at future professional needs. Moreover, it should form such a level of professional and general culture that will allow graduates to maintain high professionalism in any field of legal activity (legislative, executive, judicial, notary, operative-investigative, scientific-educational, etc.). One of the important components of a lawyer's professional competence is language, speech and communicative competence, the lack of which significantly lowers a lawyer's rating, depriving him of his professional perspective.

The problem of forming professional speech competence of prospective lawyers in the context of Ukraine's integration into the European educational area is extremely urgent today. Due to the importance of the following issue, the author has chosen the topic of the scientific paper. The purpose of the article is to draw attention to the problem of increasing linguistic and speech competence of legal specialty students in higher educational establishments of Ukraine and to make clear requirements for the language and speech in the professiograms of lawyers.

Formulation of the problem. The system of higher legal science and education in Ukraine is currently facing dynamic changes related to updating the content and forms of professional training of prospective lawyers, the search for new promising models of their professional training in accordance with European requirements and professional standards. As a result the project «Concepts for reforming legal education», prepared by the Ministry of Justice of Ukraine and the Ministry of Education and Science of Ukraine on March 25, 2019, was presented for public discussion. The main aim of the new Concept is to create the conditions for modernizing the content of legal education. This project has several disadvantages, including the lack of a definition «quality legal education», lack of explanations of its educational programs' content, and uncertainty about general and professional competence of lawyers. But the most striking thing is that such key concepts as language competence, as well as the level of the command of the state language, were not mentioned in the document. Moreover, it should be noted, that it is urgent due to the Resolution of the Cabinet of Ministers of Ukraine dated April 26, 2017 No. 301» On the organization of certification of persons applying for admission to the civil service regarding the fluency in the state language» and the Law of Ukraine «On Ensuring the Functioning of Ukrainian as a state language» adopted by the Verkhovna 
Rada of Ukraine on 25.04.2019. In Article 14, paragraph 1 it is stated: «Courts shall use the official language in the course of the judicial proceedings» (the Law of Ukraine).

Analysis of recent researches and publications. The ways of improving the professional speech of future lawyers have been the main problem for the reseachers (N. Artykutsa, A. Bilonozhko, A. Kochubey, E. Tyagniryadno, M. Kryskiv, N. Chaban, T. Mozharova, O. Semenog, L. Nasilenko, O. Oliynyk, L. Fedorova, G. Onufrienko, Y. Pradid, L. Chernikov, and others. All of them emphasize the importance and necessity of compulsory study of the discipline «The Ukrainian language (for professional use)» at higher education institutions of Ukraine in legal specialties, in order to train highly qualified specialists in the field of law, who are fluent in the state language in speaking and writing. Some scholars express their opinions about the necessity to review the language training of lawyers and propose to introduce specialized language courses into the curricula of the law faculties of higher education institutions (Artikutsa, 1997; Semenog, Nasilenko 2015). So, in particular such disciplines as «Legal terms», «Legal language», «Editing and translation of legal texts», «Scientific style of legal language», «Legal journalism», «Judicial rhetoric» have been introduced at the National University «Kyiv-Mohyla Academy». At National Pedagogical University named after M.P. Drahomanov at the educational and qualification levels of «Master» there are such special educational disciplines as «Language of law and methods of its study», «Legal terms». These subjects are integrated because they synthesize the achievements of modern science in the legal and linguistic fields and help to increase students' communicative and professional competence.

Presenting main material. Lawyer's professional language is based on the laws of the modern Ukrainian language, its orthoepic, spelling, lexical, stylistic, morphological, syntactic and punctuation norms. Language is the first element of law. The language forms regulatory acts, texts of laws, etc. The language of a lawyer is closely connected not only with the generally accepted lexical and grammatical rules, but also with the requirements of legislative technique, needs and specifics of jurisprudence.The profession of a lawyer requires the use of accurate verbal expressions, legal notions, terms associated with the preparation and processing of various documents, with giving and getting information in oral and written form. According to N. V. Artikutsy's (1997), hardly in any other kind of written (and also oral) speech the external form of expression has such great and sometimes fatal value (in the life of the individual and the state as a whole), as well as in jurisprudence (Artikutsa, 1997). Even the incorrect punctuation mark can radically change the content of the text of the law. In turn grammatical errors in the documents lead to negative legal consequences. The inability of a lawyer to prepare a courtroom speech correctly, with clear intonation, and give a speech confidently and convincingly to pronounce is the reason for the failure during the court session. Consequently, all 
mentioned above causes the inability of a lawyer to fulfill his professional duties in protecting the interests of the defendant properly, etc.

It should be noted that legal professions are very diverse and each of them is related to speech, with its specific aspects. Such characteristics as correct speech and accuracy of speech are of high importance. In order to follow them we need, on the one hand, legal terms, and, on the other, specialized vocabulary of those areas that we need to deal with and also data used by lawyers due to the certain court proceedings. So, there is no doubt that the requirements for speech should have been represented in the professiograms of lawyers. Unfortunately, it doesn't take place.

Let's define and analyze the linguistic and communicative competence of the most common legal professions, such as a judge, a prosecutor, a lawyer, a notary. In the monograph «Professional Communication Training of Future Lawyers: Theory and Practice», written by O. M. Semenog, L. A. Nasilenko (Semenog, Nasilenko, 2015) the authors describe communicative and linguistic competence.

A judge should know the peculiarities of communication with his colleagues, clients, be able to listen to witnesses, experts carefully, be able to ask questions, answer clearly and comprehensively, convey and express the content of verbal messages, speak publicly at court sessions, justify and make decisions in law regulatory and enforcement proceedings. The speech and written language of a judge (protocol, sentence) should be marked by conciseness, clarity of statements (Semenog, 2015, p. 28).

A prosecutor participates in court proceedings, prepares the indictment, gives evidence and proves them in the course of the defense controversy. So, he should have logical thinking, the ability to analyze the facts deeply. Besides he is supposed to conduct a qualified analysis of the evidence, convince other court session participants of the truth of the evidence, make sound legal decisions. In the course of the court proceedings, a prosecutor communicates with lawyers, experts, defendants, victims, witnesses, and he should find an appropriate approach, an appropriate word to each of them (Semenog, 2015, p. 29).

A lawyer, also called an attorney, counseling clients about legal options and representing them in criminal or civil court proceedings, should be able to provide the legal advice; advance the interests of a client, make complaints and other legal documents on behalf of his clients; perform legal services and represent a client in a court in the inquiry and preliminary investigation. An important component of a lawyer's professional activity is his explanations in the court of cassation. He should be able to state his view point in a qualified manner, to justify his conclusions. Moreover his communication style with clients and defendants should promote mutual trust (Semenog, 2015, p. 29-30).

A notary is an official who writes his official signature and stamps or seals various legal documents according to the state law (contracts, wills, letters of attorney, warrants, marriage contracts, etc.). Work with legal documents requires advanced 
writing skills, professional knowledge of Documentation. The ability to conduct professional dialogue is an important ability for him: he should consult, explain, ask questions and answer them in a qualified manner (Semenog, 2015, p. 30).

Thus, the professional competences' review of the most widespread legal professions shows that lawyers of all specialties should have language, speech and communication skills and abilities, interpret and analyze facts and circumstances, various legal texts (laws, regulations, etc.) properly; make agreements and legal documents; to give qualified legal advice; to carry out legal actions in exact accordance with the law (accusatory, defensive speech, participation in court debates, speech situation of interrogation), etc.

It is extremely important for first year students to be aware of the linguistic peculiarities of law, the text of the law, the skills of a careful attitude toward the linguistic expression of legal norms (Artikutsa, 1995). The process of teaching the first-year law students of KNTEU as well as the results of the entry rectorial control show poor communication skills.

The students often, neglect the Ukrainian standard language, preferring mixed Russian-Ukrainian dialect. They do not feel confident in class and take a long of time searching for the suitable Ukrainian word in a particular communicative situation. This can be explained by the students' narrow vocabulary. Legal specialty students are afraid of participating in discussions, expressing their opinions. Serious drawbacks of students' speech are such as parasite words, monotony, lack of expression, fear of audience, and inability to speak in public. Consequently, it is so important for prospective lawyers to prepare themselves for professional activity during their studies at the university not only by mastering the compulsory disciplines that form the basis of professional training, but also to develop oral and written professional language skills and to form speech competence.

To improve the linguistic training of future lawyers in the curricula of Kyiv National University of Trade and Economics, the students need to study the discipline « the Ukrainian language (for professional use)», which aims to form a high level of communicative culture in the sphere of professional communication in its oral and written forms; to develop skills of practical command of the language in different types of speech activity due to professional needs.

As a result of studying the discipline «the Ukrainian language (for professional use)» students of law specialties should develop the following necessary abilities and skills:

1) oral speech: to monitor the purity and correctness of speech (absence of parasites, profanity); to express one's opinion accurately; to choose words from a synonymic chain which convey the meaning of the utterance as well as relate to the communicative situation; to use various language means to persuade the interlocutors; to use the right word stress, to pronounce words correctly, to follow the expressiveness of the diction; to be able and appropriate to use pauses, different intonation types and speech tempo to highlight important information; to build phrases and sentences 
in different professional texts correctly; to make presentations with minimum use of notes confidently; to participate in discussions; to ask questions, answer clearly and comprehensively, give convincing arguments, etc. It is appropriate to use linguistic etiquette formulas depending on the communication situation (patterns of appeal to the familiar or unfamiliar, courtesy, apology, agreement, disagreement, etc.), aphorisms, quotes, proverbs, etc.

2) written language: draft and edit professional documents of various types: applications (a letter of application, memorandum, statement of claim); orders and instructions (one-off, special, general); protocols, decisions, acts, complaints, wills, agreements, contracts, etc.); texts of legislative and legal normative acts; different types of court speech texts; justify and formulate the texts of legislative and legal normative acts.

Conclusion. Thus, the formation level of linguistic, speech and communicative competence of future lawyers is an indicator of their readiness for professional activity, as well as a necessary precondition and a means of their professional selfrealization. Therefore, we consider the study of the discipline «the Ukrainian language (for professional use)» to be compulsory in their professional training. Moreover the requirements for language and speech should be included in the professiograms of legal specialists.

\section{REFERENCES}

1. Zakon Ukrainy «Pro zabezpechennia funktsionuvannia ukrainskoi movy yak derzhavnoi» vid 25.04.2019 [Elektronnyi resurs]. - Rezhym dostupu : https://zakon.rada.gov.ua/laws/show/2704-19 [in Ukrainian].

2. Artykutsa N. V. (1997). Novi pidkhody do movnoi pidhotovky maibutnikh yurystiv i vykladachiv prava / N. V. Artykutsa // PravoUkrainy. - № 12. - S. 58-60 [in Ukrainian].

3. Semenoh O. M., Nasilienko L. A. (2015). Profesiina komunikatyvna pidhotovka maibutnikhy urystiv: teoriia i praktyka: [monohrafiia]. - Sumy : Vyd-vo Sum DPUimeni A. S. Makarenka. - 324 s. [in Ukrainian].

4. Katsavets R. S. (2017). Mova derzhavnykh sluzhbovtsiv : Navchalnyi posibnyk. - K. : Pravova yednist [in Ukrainian].

5. Postanova Kabinetu Ministriv Ukrainy vid 26 kvitnia 2017 r. № 301 «Pro orhanizatsiiu provedennia atestatsii osib, yaki pretenduiut na vstupna derzhavnu sluzhbu, shchodovilno hovolodinnia derzhavnoiu movoiu» [Elektronnyi resurs]. Rezhym dostupu: https://zakon.rada.gov.ua/laws/show/301-2017-\%D0\%BF [in Ukrainian].

6. Fedorova L. M. (2019). Profesiine movlennia maibutnikh yurystiv. // Materialy Mizhvuzivskoho naukovo-metodychnoho seminaru «Formuvannia profesionalizmu molodi vs ystemi bezperervnoi osvity». - Kyiv : Kyiv. nats. torh.-ekon. un-t. - S. 114-117 [Elektronnyi resurs]. - Rezhym dostupu : https://knute.edu.ua/file/NjY4NQ==/ dc5d1c0a98b1343d22ae9b618a95d144.pdf [in Ukrainian]. 